\title{
Spatial and temporal shifts in the diet of the barnacle Amphibalanus eburneus within a subtropical estuary
}

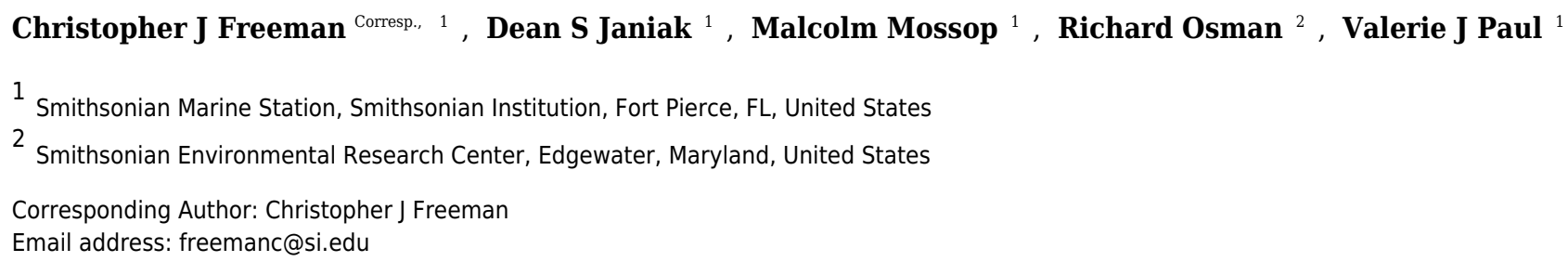

The success of many sessile invertebrates in marine benthic communities is linked to their ability to efficiently remove suspended organic matter from the surrounding water column. To investigate the diet of the barnacle Amphibalanus eburneus, a dominant suspension feeder within the Indian River Lagoon (IRL) of central Florida, we compared the stable isotopes ratios $\left(\delta^{13} \mathrm{C}\right.$ and $\left.\delta^{15} \mathrm{~N}\right)$ of barnacle tissue to those of particulate organic matter (POM). Collections were carried out quarterly for a year from 29 permanent sites and at sites impacted by an Aureoumbra lagunensis bloom. $\delta^{13} \mathrm{C}$ and $\delta^{15} \mathrm{~N}$ values of $A$. eburneus varied across sites, but $\delta^{15} \mathrm{~N}$ was more stable over time. There was a range of $\delta^{15} \mathrm{~N}$ values of $A$. eburneus tissue from $6.0 \%$ to $10.5 \%$ across sites. Because land-based sources such as sewage are generally enriched in ${ }^{15} \mathrm{~N}$, this suggests a continuum of anthropogenic influence across sites in the IRL. Over $70 \%$ of the variation in $\delta^{15} \mathrm{~N}$ values of $A$. eburneus across sites was driven by the $\delta^{15} \mathrm{~N}$ values of POM, supporting a generalist feeding strategy on available sources of suspended organic matter. The dominance of this generalist consumer in the IRL may be linked to its ability to consume spatially and temporally variable food resources derived from natural and anthropogenic sources, as well as $A$. lagunensis cells. Generalist consumers such as $A$. eburneus serve an important ecological role in this ecosystem and act as a sentinel species and recorder of local, site-specific isotopic baselines. 
1 Spatial and temporal shifts in the diet of the barnacle Amphibalanus eburneus within a

2 subtropical estuary

3

4 Christopher J Freeman', Dean S Janiak ${ }^{1}$, Malcolm Mossop ${ }^{1}$, Richard Osman ${ }^{2}$, and Valerie

5 J Paul $^{1}$

$6 \quad{ }^{1}$ Smithsonian Marine Station, Fort Pierce, Florida, USA

$7 \quad{ }^{2}$ Smithsonian Environmental Research Center, Edgewater, Maryland, USA

8

9 Corresponding Author: Dr. Christopher Freeman, Smithsonian Marine Station, 701

10 Seaway Drive, Fort Pierce, FL 34949;

11 Email address: $\underline{\text { freemanc@si.edu }}$

12

13

14

15

16

17

18

19

20

21

22

23 


\section{Abstract:}

25 The success of many sessile invertebrates in marine benthic communities is linked to 26 their ability to efficiently remove suspended organic matter from the surrounding water column. 27 To investigate the diet of the barnacle Amphibalanus eburneus, a dominant suspension feeder 28 within the Indian River Lagoon (IRL) of central Florida, we compared the stable isotopes ratios $29\left(\delta^{13} \mathrm{C}\right.$ and $\left.\delta^{15} \mathrm{~N}\right)$ of barnacle tissue to those of particulate organic matter (POM). Collections were carried out quarterly for a year from 29 permanent sites and at sites impacted by an Aureoumbra lagunensis bloom. $\delta^{13} \mathrm{C}$ and $\delta^{15} \mathrm{~N}$ values of $A$. eburneus varied across sites, but $\delta^{15} \mathrm{~N}$ was more stable over time. There was a range of $\delta^{15} \mathrm{~N}$ values of $A$. eburneus tissue from $6.0 \%$ to $10.5 \%$ across sites. Because land-based sources such as sewage are generally enriched in ${ }^{15} \mathrm{~N}$, this suggests a continuum of anthropogenic influence across sites in the IRL. Over $70 \%$ of the variation in $\delta^{15} \mathrm{~N}$ values of $A$. eburneus across sites was driven by the $\delta^{15} \mathrm{~N}$ values of POM, supporting a generalist feeding strategy on available sources of suspended organic matter. The dominance of this generalist consumer in the IRL may be linked to its ability to consume spatially and temporally variable food resources derived from natural and anthropogenic sources, as well as $A$. lagunensis cells. Generalist consumers such as $A$. eburneus serve an important ecological role in this ecosystem and act as a sentinel species and recorder of local, site-specific 41 isotopic baselines.

\section{Introduction}



ecosystems (Ricciardi and Bourget 1999; Riisgård and Larsen 2010). By efficiently consuming both living cells and detritus, suspension feeders play critical roles in the regulation of primary production and benthic-pelagic coupling of nutrients and organic matter (Gili and Coma 1998). This feeding mechanism is widely successful in estuarine and coastal ecosystems, and coincides with highly diverse communities in benthic habitats (Karlson and Osman 2012; Cresson, Ruitton, \& Harmelin-Vivien, 2016). Suspension feeders encounter various forms of organic matter that change over space and time (Richoux, Vermeulen, \& Froneman, 2014). These sources of nutrition vary in size and quality and can include bacteria [from $<2 \mu \mathrm{m}$ ], phytoplankton [2-200 $\mu \mathrm{m}]$, zooplankton, and detritus from terrestrial plants, phytoplankton, and submerged aquatic vegetation (Deegan and Garritt 1997; Hsieh et al., 2000; Cresson, Ruitton, \& Harmelin-Vivien, 58 2016).

Although suspension feeders appear to be ecologically similar and can occupy overlapping niches within a habitat, there is substantial variation in the feeding structures and mechanisms of coexisting species (Stuart and Klumpp 1984; Lesser et al., 1992; Riisgård and Manríquez 1997; Karlson, Gorokhova, \& Elmgren, 2015). This variation impacts an organism’s ability to acquire, sort, and select food particles and may allow individual species to specialize in a subset of available suspended particulate matter (Dubois et al., 2007a; Riisgård and Larsen 2010; Dubois and Colombo 2014; Richoux, Vermeulen, \& Froneman, 2014; Cresson, Ruitton, \& Harmelin-Vivien, 2016; Whalen and Stachowicz 2017). For example, bivalves are able to sort and selectively feed on particles, releasing inorganic matter via pseudofeces and efficiently retaining high quality particles greater than $5 \mu \mathrm{m}$ (Jorgensen 1974; Møhlenberg and Riisgård 
70 mollusks, in contrast, largely lack structures that facilitate particle selection and are considered

71 generalist or indiscriminate suspension feeders (Lesser et al., 1992; Petersen 2007; Dubois et al.,

72 2007a; Cresson, Ruitton, \& Harmelin-Vivien, 2016). These generalists are, however, capable of

73 retaining a broader range of particles that may not be consumed by selective suspension feeders

74 or even adopting an omnivorous nutritional strategy that allows them to feed at higher trophic

75 levels (Lesser et al., 1992; Bone, Carre, \& Chang, 2003; Petersen 2007; Decottignies et al., 2007;

76 Beninger et al., 2007; Kach and Ward 2008; Riisgård and Larsen 2010; Richoux, Vermeulen, \&

77 Froneman, 2014; Cresson, Ruitton, \& Harmelin-Vivien, 2016).

78 Coastal ecosystems are subject to seasonal shifts in environmental conditions and strong

79 resource gradients from a combination of inputs from marine and terrestrial sources (Deegan and

80 Garritt 1997). In addition, food webs in these systems are increasingly impacted by

81 anthropogenically-derived pollution and harmful algal blooms (Carlton, Newman, \& Pitombo,

82 2011; Lapointe et al., 2015; Galimany et al., 2017b). Divergence in feeding mechanisms among

83 coexisting suspension feeders may lead to differential responses of species to these changes and

84 shape community composition across sites (Dubois et al., 2007a; Cresson, Ruitton, \& Harmelin-

85 Vivien, 2016). Trophic plasticity may allow generalist species to exploit a broader range of

86 ecological niches and adapt to both natural and anthropogenic changes in food availability.

87 Barnacles, for instance, are a dominant component of many intertidal and estuarine ecosystems

88 and are one of the most prolific invaders into coastal ecosystems worldwide (Carlton, Newman,

$89 \&$ Pitombo, 2011). Their success is likely linked to their ability to consume a wide range of

90 particle sizes from zooplankton to phytoplankton (down to 2-5 $\mu \mathrm{m}$ ), detritus, and organic matter

91 from both natural and anthropogenic sources (Barnes, 1959; Crisp and Southward, 1961; Lesser

92 et al., 1992; Riisgård and Larsen 2010; Dolenec et al., 2016) The diet of barnacles has also been 
93 shown to vary over space and time (Dolenec et al., 2006; Dubois et al., 2007a; Dubois et al.,

94 2014; Dubois and Colombo 2014; Richoux, Vermeulen, \& Froneman, 2014) resulting from shifts

95 in organic matter composition.

96 The Indian River Lagoon (IRL) of central Florida is a subtropical, shallow (mean depth

97 of $<1 \mathrm{~m}$ ) estuary that spans $250 \mathrm{~km}$ of the east coast of central Florida. The IRL supports a high

98 diversity of marine species due to a variety of habitats (mangrove, seagrass, oyster reefs, and

99 artificial substrates) and its location in a tropical/temperate transition zone in close proximity to

100 the Gulf Stream (Gilmore 1995; Swain et al., 1995). Like many estuaries, both acute and chronic

101 stressors are increasingly impacting communities within the IRL, leading to cascading effects

102 throughout local food webs. For example, nutrient loading (Lapointe et al., 2015) and the loss of

103 planktonic grazers have led to an increased frequency and severity of algal blooms (Phlips et al.,

104 2014). The "superbloom" of a Picocyanobacteria and a Pedinophyceae (both 1-2 $\mu \mathrm{m}$ ) sp. in 2011

105 and blooms of the brown tide Aureoumbra lagunensis (4-5 $\mu \mathrm{m})$ in 2012, 2013, and the winter of

1062016 (St. John’s River Water Management District [SJRWMD] 2013; Phlips et al., 2014;

107 Kamerosky, Cho, Morris, 2015; Lapointe et al., 2015) were particularly devastating within the

108 sublagoons of the northern IRL (NIRL). Although these algal species are all non-toxic, high

109 concentrations of algal cells blocked sunlight from reaching seagrass beds and, ultimately,

110 resulted in hypoxic events that led to fish kills within the NIRL (Phlips et al., 2014).

111 Surveys of epifauna communities at 90 sites in the NIRL have found high species

112 diversity (175 taxa on 11 phyla) and a dominance of the barnacle Amphibalanus eburneus, with a

113 mean percent cover of $30 \%$ to $40 \%$ across sites (D.S. Janiak unpublished under review; Fig. S1

114 in supplemental information). The success of $A$. eburneus across sites in the NIRL may be linked

115 to its generalist feeding on available sources of suspended organic matter, but little is known 
116 about how the diet of A. eburneus changes over time and space and whether these changes mirror

117 general shifts in particulate organic matter. To investigate this, we compared the stable isotope

118 ratios $\left(\delta^{13} \mathrm{C}\right.$ and $\left.\delta^{15} \mathrm{~N}\right)$ of $A$. eburneus tissue to that of particulate organic matter (POM) from the

119 water column. Collections were carried out quarterly for a year and also during an Aureoumbra

120 lagunensis bloom. We tested the following hypotheses: (1) the $\delta^{13} \mathrm{C}$ and $\delta^{15} \mathrm{~N}$ values of $A$.

121 eburneus vary over space and time and will be closely tied to the $\delta^{13} \mathrm{C}$ and $\delta^{15} \mathrm{~N}$ values of POM,

122 and (2) A. eburneus will demonstrate shifts in $\delta^{13} \mathrm{C}$ and/or $\delta^{15} \mathrm{~N}$ values that indicate consumption

123 of the brown tide Aureoumbra lagunensis.

124 Materials and Methods:

125 Sample Collection

126 As part of a project monitoring epifaunal community composition and diversity over

127 space and time, we established 29 permanent monitoring sites spanning $150 \mathrm{~km}$ within the three

128 sub-lagoons (Indian River and Mosquito Lagoons, and the Banana River) of the northern region

129 of the greater Indian River Lagoon (NIRL; Fig. 1; Table S1). Collections of Amphibalanus

130 eburneus $(\mathrm{N}=5-10$ individuals) were carried out at each of these monitoring sites on a quarterly

131 basis (in January, April, July, and October of 2015). Permits for species collections were

132 provided by the Florida Fish and Wildlife Conservation Commission (SAL-14-1567-SR). To test

133 whether a bloom of Aureoumbra lagunensis influenced the diet of A. eburneus, samples were

134 also collected opportunistically at sites within the Banana River and Indian River Lagoon that

135 were influenced by A. lagunensis from December of 2015 to March of 2016 (Fig. S2; Galimany

136 et al., 2017a). Barnacles were removed from mangrove prop roots or artificial substrates (dock

137 and bridge pilings or seawalls) using a paint scraper and placed into a $4 \mathrm{~L}$ plastic bag containing 
138 seawater for transit back to the Smithsonian Marine Station (SMS). There were missing data for

139 some sites on particular dates resulting from sample loss or inaccessibility.

140 During seasonal and A. lagunensis collections, a sample of seawater (20 L) for particulate

141 organic matter (POM) was also taken at each site to monitor the $\delta^{13} \mathrm{C}$ and $\delta^{15} \mathrm{~N}$ values of general

142 sources of particulate carbon and nitrogen available to A. eburneus. In the laboratory, this

143 seawater was prefiltered through $105 \mu \mathrm{m}$ mesh and then filtered through a Millepore quartz fiber

144 filter ( $2 \mu \mathrm{m}$ porosity) stacked on top of a Whatman glass fiber (GF) filter ( $0.7 \mu \mathrm{m}$ porosity) to

145 obtain a single POM sample for each time point at each site. The organic matter content on GF

146 filters was below detection limits, so POM $\delta^{13} \mathrm{C}$ and $\delta^{15} \mathrm{~N}$ values are based on the results from

147 organic matter on quartz fiber filters ( $2 \mu \mathrm{m}$ porosity) that were stacked on top of the GF/F.

148 Sample preparation and stable isotope $\left(\delta^{13} \mathrm{C}\right.$ and $\left.\delta^{15} \mathrm{~N}\right)$ analysis

149 Samples of A. eburneus were kept separate and held overnight in flowing, sand-filtered

150 seawater to allow for gut evacuation and then frozen at $-20^{\circ} \mathrm{C}$. Once thawed, the shell diameter

151 was measured for each individual ( $\mathrm{n}=10$ per site for each sampling period) and, using forceps, all

152 tissue within the shell of a barnacle was placed into an individual glass vial (Richoux,

153 Vermeulen, \& Froneman, 2014). Tissue was dried at $60^{\circ} \mathrm{C}$ for $24 \mathrm{~h}$ and homogenized using a

154 mortar and pestle. Homogenized samples were acidified to remove carbonate by exposure to $12 \mathrm{~N}$

$155 \mathrm{HCl}$ fumes for $12 \mathrm{~h}$, after which samples were returned to the oven at $60{ }^{\circ} \mathrm{C}$ for $24 \mathrm{~h}$ (Freeman

156 and Thacker 2011). Quartz and GF filters containing POM were also dried and acidified prior to

157 analysis. POM was scraped from each filter, and POM from each filter and barnacle samples

158 were separately weighed to the nearest $0.001 \mathrm{mg}$ into tared tin capsules. Isotope analysis was

159 carried out at the Stable Isotope Facility at UC Davis using a PDZ Europa ANCA-GSL (for

160 barnacle tissue samples) or Micro Cube (for POM samples) elemental analyzer interfaced to a 
161 PDZ Europa 20-20 isotope ratio mass spectrometer (Sercon Ltd., Cheshire, UK). Isotope values

162 are reported in $\delta$ notation in units of permille (\%).

163 Data Analysis

164 Isotope values provide a time-integrated record of an organism's diet, with $\delta^{13} \mathrm{C}$ values

165 providing information about the primary sources of carbon fueling local food webs and $\delta^{15} \mathrm{~N}$

166 values acting as a proxy for trophic level and the sources of nitrogen assimilated (Michener and

167 Kaufman 2007). To test the effect of season and site on the placement of A. eburneus samples

168 within bivariate $\left(\delta^{13} \mathrm{C}\right.$ and $\left.\delta^{15} \mathrm{~N}\right)$ isotopic space, we calculated isotopic dissimilarity (measured as

169 Euclidean distance) among samples and analyzed dissimilarity using a permutational

170 multivariate analysis of variance (PERMANOVA) (Primer 6 with PERMANOVA+ add-on).

171 Seasonal variation in individual isotope values was assessed using a Kruskal-Wallis One-Way

172 Analysis of Variance (ANOVA). Linear regressions were used to investigate the relationship

173 between the $\delta^{13} \mathrm{C}$ and $\delta^{15} \mathrm{~N}$ values of $A$. eburneus tissue and the $\delta^{13} \mathrm{C}$ and $\delta^{15} \mathrm{~N}$ values of POM at

174 each site. These analyses were carried out using Systat.

175 Results

176 There was significant variation in the $\delta^{15} \mathrm{~N}$ and $\delta^{13} \mathrm{C}$ values of $A$. eburneus tissue over

177 space and time (PERMANOVA testing the effect of site $\left[{ }_{\text {sseudo }} F_{29,1046}=23.89 ; p_{(\text {perm })}=0.001\right]$ and

178 season $\left.\left[{ }_{P_{\text {seudo }}} F_{3,1072}=140.6 ; p_{(\text {perm })}=0.001\right]\right)$ (Fig. 2a and 3a; Fig. S3 in supplemental information)

179 during annual collections. Within each season, $\delta^{15} \mathrm{~N}$ and $\delta^{13} \mathrm{C}$ values also varied among sites

180 (PERMANOVA testing the effect of individual site nested within collection period:

$\left.181 P_{\text {seudo }} F_{96,976}=56.58 ; p_{(\text {perm })}=0.001\right)\left(\right.$ Fig. S3). Annual mean $\delta^{15} \mathrm{~N}$ values from each site ranged from

$1826.0 \%$ to $10.5 \%$, with depleted $\left(6.0 \%\right.$ to $7.7 \%$ ) $\delta^{15} \mathrm{~N}$ values in the northern region of the IRL

183 (site \#s I1-5) and in the Mosquito Lagoon (site \#s M1-6) compared to sites in the Banana River 
184 and the southern IRL (site \#s B and I6-13) that had $\delta^{15} \mathrm{~N}$ values between $8.3 \%$ and $10.5 \%$ (Fig.

185 2a). Annual mean $\delta^{13} \mathrm{C}$ values ranged from $-22.3 \%$ to $-17.8 \%$, with variation at finer spatial

186 scales (within lagoons and even between geographically adjacent sites) than $\delta^{15} \mathrm{~N}$ values (Fig. 3a

187 and Fig. S3). In addition, $\delta^{13} \mathrm{C}$ values varied more across seasons than $\delta^{15} \mathrm{~N}$ values (Kruskal-

188 Wallis: $H: 506_{3} ; p<0.001$ and $H: 10.2_{3}, p<0.05$ for $\delta^{13} \mathrm{C}$ and $\delta^{15} \mathrm{~N}$, respectively) (Fig. 2a and 3a;

189 Fig. S3).

190

The $\delta^{13} \mathrm{C}$ and $\delta^{15} \mathrm{~N}$ values of particulate organic matter (POM) varied across space and

191 time (Figs. 2b, 3b, and 4; Fig. S4), with a range of annual means from $-24.6 \%$ to $-20 \%$ and 3.3

$192 \%$ to $8.2 \%$ for $\delta^{13} \mathrm{C}$ and $\delta^{15} \mathrm{~N}$, respectively. The average $\delta^{13} \mathrm{C}$ and $\delta^{15} \mathrm{~N}$ values of POM at each

193 site explained $22 \%$ and $71 \%$ of the variation in the mean $\delta^{13} \mathrm{C}$ and $\delta^{15} \mathrm{~N}$ values of Amphibalanus

194 eburneus at the same site (linear regression: $r^{2}=0.22 ; p<0.01 ; \mathrm{N}=35$ and $r^{2}=0.71 ; p<0.001$;

$195 \mathrm{~N}=35$ for $\delta^{13} \mathrm{C}$ and $\delta^{15} \mathrm{~N}$ values, respectively) (Fig. 4 and Fig. S4 for individual site values for

196 each season). Tissue values of $A$. eburneus were, on average, enriched in both $\delta^{15} \mathrm{~N}$ and $\delta^{13} \mathrm{C}$

197 compared to POM $\left(+2.78 \pm 0.15 \mathrm{SE}\right.$ and $+1.76 \pm 0.17 \mathrm{SE}$ for $\delta^{15} \mathrm{~N}$ and $\delta^{13} \mathrm{C}$, respectively (Fig.

198 4; Fig. S4).

$199 \delta^{15} \mathrm{~N}$ of A. eburneus tissue was between $9.1 \%$ to $13.1 \%$ during the Aureoumbra

200 lagunensis bloom, with an average enrichment of $1.8 \%$ (range of $0.7 \%$ to $2.7 \%$ ) compared to

201 annual mean values (Fig. 2a, 4a, and 5; Fig. S3). Likewise, $\delta^{13} \mathrm{C}$ of $A$. eburneus tissue during the

202 Aureoumbra bloom ranged from $-21 \%$ to $-19 \%$, with a mean enrichment of $0.9 \%$ (range of -

$2030.2 \%$ to $2.1 \%$ ) compared to the annual mean at a site (Fig. 3a, 4b, and 5; Fig. S3). The $\delta^{15} \mathrm{~N}$

204 and $\delta^{13} \mathrm{C}$ values of POM were variable during the A. lagunensis bloom, with enrichment at some,

205 but not all sites (mean enrichment of $0.3 \%$ [range of $-1 \%$ to $1.6 \%$ ] and $-0.4 \%$ [range of -4.6

$206 \%$ to $2.7 \%$ ] for $\delta^{15} \mathrm{~N}$ and $\delta^{13} \mathrm{C}$, respectively) relative to the annual mean (Fig. 2b, 3b, and Fig. 4; 
207 Fig. S4). Tissue values of A. eburneus were enriched in both $\delta^{15} \mathrm{~N}$ and $\delta^{13} \mathrm{C}$ relative to POM 208 under bloom conditions $(+4.37 \pm 0.30 \mathrm{SE}$ (range +3.47 to +5.9$)$ and $+1.91 \pm 0.75 \mathrm{SE}$ (range 2091.59 to +4.83 ) for $\delta^{15} \mathrm{~N}$ and $\delta^{13} \mathrm{C}$, respectively (Fig. 4; Fig. S4).

\section{Discussion}

211 Trophic ecology of Amphibalanus eburneus

212 The $\delta^{13} \mathrm{C}$ and $\delta^{15} \mathrm{~N}$ values of POM suggest that particulate sources of organic matter vary 213 across seasons and small spatial scales in the IRL. Variation in $\delta^{13} \mathrm{C}$ values is likely due to inputs 214 of organic carbon from a combination of marine phytoplankton $\left(\delta^{13} \mathrm{C}\right.$ values of $-18 \%$ to $-24 \%$ ) 215 and detritus from terrestrial $C_{3}$ plants such as mangroves (-35 \%o to $\left.-25 \%\right)$ and seagrasses $(-13.5$ $216 \%$ and -5.2 \%) (Deegan and Garritt 1997; Michener and Kaufman 2007). Likewise, the $\delta^{15} \mathrm{~N}$ 217 values of POM provide information about the sources of nitrogen fueling local food webs. For 218 instance, while depleted $\delta^{15} \mathrm{~N}$ values suggest natural $\mathrm{N}$-fixation, elevated $\delta^{15} \mathrm{~N}$ values $(>3 \%)$ are 219 suggestive of nitrogen derived from ${ }^{15} \mathrm{~N}$-enriched sources such as wastewater (Lapointe et al., 220 2015). POM $\delta^{15} \mathrm{~N}$ values in our study that range from $\sim 3$ to $8 \%$ therefore suggest a continuum 221 of impact from anthropogenically-derived nutrients across sites in the IRL. High levels of 222 dissolved inorganic nitrogen (DIN) and total dissolved nitrogen (TDN) have been reported 223 previously in regions of the northern IRL resulting from long water residence times and inputs of 224 anthropogenically-derived nitrogen via surface water runoff and groundwater from septic tanks 225 (Smith et al., 1993; Lapointe et al., 2015). Our data suggest that sites close to human 226 development in the Banana River and southern sites in the Indian River $\left(\delta^{15} \mathrm{~N}\right.$ values of $\sim 6$ to 8

$227 \%$ ) are more impacted by these ${ }^{15} \mathrm{~N}$-enriched sources than those in the more sparsely populated 228 Mosquito Lagoon and northern IRL sites; our POM values are in general agreement with the 
229 magnitude of ${ }^{15} \mathrm{~N}$ enrichment found in macroalgae from this region of the IRL (Lapointe et al., 230 2015).

231 The isotopic composition of $A$. eburneus tissue was coupled to the temporal and spatial 232 dynamics of POM $\delta^{15} \mathrm{~N}$ and, to a lesser extent, $\delta^{13} \mathrm{C}$ values, supporting the contention that 233 barnacles are generalist suspension feeders utilizing predominant components of the organic 234 matter pool in the water column (Cresson, Ruitton, \& Harmelin-Vivien, 2016). In contrast, if 235 barnacles had a broader capacity to sort and select particles based on size or nutritional quality, 236 we would expect less variation in the $\delta^{13} \mathrm{C}$ and $\delta^{15} \mathrm{~N}$ of barnacle tissue over time and space and a 237 decoupling of POM and A. eburneus isotope values (Decottignies et al., 2007; Dubois et al., 238 2007a; Dubois and Colombo 2014). For example, in the oyster Crassostrea gigas, the $\delta^{13} \mathrm{C}$ and $239 \delta^{15} \mathrm{~N}$ values of POM explained less than $5 \%$ of the variation in isotope values of oyster muscle 240 tissue (Marchais et al., 2013). Although this relationship was significant in our study (explaining 24171 and $22 \%$ of the variance for mean $\delta^{15} \mathrm{~N}$ and $\delta^{13} \mathrm{C}$ values at each site, respectively), the trend 242 may have been even stronger if we had finer temporal resolution instead of a single POM isotope 243 "snapshot" for each season from a site. The tissue of $A$. eburneus was generally enriched in ${ }^{13} \mathrm{C}$ 244 and ${ }^{15} \mathrm{~N}$ (higher $\delta^{13} \mathrm{C}$ and $\delta^{15} \mathrm{~N}$ values) relative to POM (by $+1.76 \%$ and $+2.78 \%$, respectively).

245 Because consumers are generally enriched in both ${ }^{13} \mathrm{C}$ and ${ }^{15} \mathrm{~N}$ due to the process of trophic 246 enrichment, this implies the presence of a "trophic step" between particulate matter and $A$.

247 eburneus (Dubois et al., 2007b). The magnitude of trophic enrichment varies across species, but 248 is generally hypothesized to range from $<1.0 \%$ to $2.0 \%$ for $\delta^{13} \mathrm{C}$ and $3.0 \%$ to $3.6 \%$ for $\delta^{15} \mathrm{~N}$ 249 (DeNiro and Epstein 1981; Zanden and Rasmussen 2001; McCutchan et al., 2003; Dubois et al., 250 2007b). Our values are therefore well within the estimated range for trophic enrichment, 251 supporting generalist feeding on bulk POM by A. eburneus (Hsieh et al., 2000). 
253 such as zooplankton (Richoux, Vermeulen, \& Froneman, 2014). Enriched $\delta^{15} \mathrm{~N}$ values of $A$.

254 eburneus from the IRL may therefore reflect feeding on zooplankton (Dix and Hanisak 2015).

255 We posit, however, that if zooplankton had been a dominant component of the diet of $A$.

256 eburneus in the IRL, we would have observed an additional trophic step between POM

257 (predominately phytoplankton) and A. eburneus tissue isotope values. Enriched $\delta^{15} \mathrm{~N}$ values are

258 thus likely the result of the passage of anthropogenically-derived nitrogen assimilated by

259 phytoplankton into the epifaunal food web. Enriched $\delta^{15} \mathrm{~N}$ values in POM and barnacle tissue at

260 sites impacted by anthropogenically-derived nutrients has been reported before in other systems,

261 with up to a $5 \%$ enrichment in barnacles from impacted sites and strong linear correlations

262 between POM and barnacle $\delta^{15} \mathrm{~N}$ values (Dolenec et al., 2006, 2007). Elevated $\delta^{15} \mathrm{~N}$ values of

263 POM and A. eburneus tissue ( $>8 \%$ ) in the more urbanized regions of the NIRL (Banana River

264 and southern sites in the Indian River) and relatively stable $\delta^{15} \mathrm{~N}$ values across seasons therefore

265 suggest chronic exposure to nitrogen from anthropogenic sources at some sites. In contrast, $\delta^{13} \mathrm{C}$

266 values within a site were more variable over both space and time, implying shifts in carbon

267 sources over small spatial scales and the potential for seasonal fluctuations in phytoplankton

268 productivity or growth rates (Cifuentes, Sharp, \& Fogel, 1988). It is possible that higher

269 variability in $\delta^{13} \mathrm{C}$ values of $A$. eburneus tissue over time may be due to differences in the

270 turnover rate of this isotope relative to $\delta^{15} \mathrm{~N}$ (Dubois et al., 2007b), but little is currently known

271 about the turnover rate of carbon and nitrogen isotopes in barnacles.

272 Amphibalanus eburneus and Algal Blooms

273 The IRL has been exposed to multiple, acute algal blooms over the past decade, with a

274 particularly detrimental superbloom in 2011 and recurring Aureoumbra lagunensis blooms in 
275 2012, 2013, and 2016 (Phlips et al., 2014; Galimany et al., 2017a). The Aureoumbra bloom in

2762016 occurred after we had gathered a year of baseline quarterly sampling on $A$. eburneus

277 feeding in the NIRL, providing an opportunity to investigate how the trophic ecology of $A$.

278 eburneus changes during an algal bloom. A single "snapshot" assessment of the $\delta^{15} \mathrm{~N}$ and $\delta^{13} \mathrm{C}$

279 values of POM during the Aureoumbra bloom demonstrated $\delta^{15} \mathrm{~N}$ values that were at or above

280 annual means and $\delta^{13} \mathrm{C}$ values that were highly variable, with evidence of both enrichment and

281 depletion in $\delta^{13} \mathrm{C}$ relative to annual means. In contrast, a more time integrated assessment (via

$282 \delta^{15} \mathrm{~N}$ and $\delta^{13} \mathrm{C}$ values of $A$. eburneus tissue) revealed that $\delta^{15} \mathrm{~N}$ and, to a lesser extent, $\delta^{13} \mathrm{C}$ values

283 of A. eburneus were enriched during the Aureoumbra bloom compared to annual means. For

$284 \delta^{13} \mathrm{C}$, this shift likely reflects a combination of source homogenization (predominately

285 Aureoumbra) and isotopic fractionation associated with algal growth and high productivity that

286 alters the $\delta^{13} \mathrm{C}$ signal at the base of the food web (Cifuentes, Sharp, \& Fogel, 1988). Although the

287 average enrichment of $\delta^{13} \mathrm{C}$ in $A$. eburneus tissue relative to POM was still within the range of a

288 trophic step (mean $1.91 \% \pm 0.75 \mathrm{SE}$ ) during the bloom, substantial variation in this enrichment

289 (range -1.59\%o to $4.83 \%$ ) suggests that direct reliance of A. eburneus on phytoplankton may be

290 reduced during blooms.

291 Enrichment of $\delta^{15} \mathrm{~N}$ (up to $13 \%$ ) may reflect increased A. eburneus consumption of

292 phytoplankton that are relying on enriched sources of anthropogenically-derived N. Although

293 blooms of Aureoumbra in the IRL have previously been shown to elicit lower POM ${ }^{15 N}$ values

294 than under non-bloom conditions (Kang, Koch, \& Gobler, 2015), Aureoumbra is also known to

295 rapidly assimilate $\mathrm{NH}_{4}$, a common component of nitrogen derived from anthropogenic sources

296 such as septic tanks (Lapointe et al., 2015; Kang, Koch, \& Gobler, 2015). We therefore propose

297 that A. eburneus may be consuming ${ }^{15} \mathrm{~N}$-enriched Aureoumbra cells at bloom sites. Alternatively, 
298 because barnacles have been shown to reduce feeding efficiency at lower particle sizes (3-5 $\mu \mathrm{m}$;

299 Lesser et al. 1992), enriched $\delta^{15} \mathrm{~N}$ values under bloom conditions may also reflect an additional

300 trophic step $\left(\delta^{15} \mathrm{~N}\right.$ values of $A$. eburneus tissue was on average enriched by $4.37 \%$ (range of

$3013.47 \%$ to $5.9 \%$ ) compared to POM during the bloom) as A. eburneus is feeding more heavily

302 on zooplankton than phytoplankton during an algal bloom. These data provide initial evidence of

303 nutritional shifts in A. eburneus under bloom conditions, but additional work in the laboratory is

304 needed to verify the role of this epifaunal species in bloom mitigation (Galimany et al., 2017b).

\section{Conclusions}

306

The generalist feeding strategy of A. eburneus appears to allow it to exploit spatially and

temporally variable sources of organic matter and may contribute to the successful dominance of

this species across sites in the NIRL (Carlton, Newman, \& Pitombo, 2011; Karlson and Osman

2012). The abundance of $A$. eburneus on diverse substrates and across both impacted and pristine

sites within the NIRL is in direct contrast to other epifaunal organisms that are more constrained

in their distribution or are currently present at only a fraction of their historical abundance (e.g.

Crassostrea virginica and Mercenaria mercenaria; MacKenzie, Taylor, \& Arnold, 2001; Wilson

313 et al., 2005; Garvis, Sacks, \& Walters, 2015; D.S. Janiak unpubl.) As a dominant and stable

314 faunal component of the NIRL, A. eburneus is likely playing an important role in nutrient and

315 organic matter cycling in this system (Dubois et al., 2007a). In addition, with a wide distribution

316 and an integration of diverse sources of carbon and nitrogen into its tissues, A. eburneus acts as

317 an important sentinel species and recorder of isotopic baselines (Post 2002; Dolenec et al., 2006;

318 Fukumori et al., 2008). Finally, its nutritional plasticity may also allow A. eburneus to capture

319 and consume bloom particles such as Aureoumbra, providing a potential means for

320 bioremediation and the prevention of algal blooms via top-down control. 


\section{Acknowledgments}

323 We thank the Smithsonian Marine Station staff and, in particular, Sherry Reed and Woody Lee

324 for their field assistance. Lab assistance was provided by A. Domingos, J. Houk, and J. Reyes.

325 This is contribution number XXXX from the Smithsonian Marine Station.

326

327

328

329

330

\section{References}

Barnes, H. 1959. Stomach contents and microfeeding of some common cirripedes. Canadian journal of Zoology 37: 231-236.

331

334

335

336

338
Beninger, P.G., P. Decottignies, F. Guiheneuf, L. Barillé, and Y. Rincé. 2007. Comparison of particle processing by two introduced suspension feeders: selection in Crepidula fornicata and Crassostrea gigas. Marine Ecology Progress Series 334: 165-177.

Bone, Q., C. Carre, and P. Chang. 2003. Tunicate feeding filters. Journal of the Marine Biological Association of the United Kingdom 83(5): 907-919.

Carlton, J.T., W.A. Newman, and F.B. Pitombo. 2011. Barnacle invasions: introduced, cryptogenic, and range expanding Cirripedia of North and South America. In In the Wrong Place-Alien Marine Crustaceans: Distribution, Biology and Impacts. eds. B.S. Galil, P.F. Clark, and J.T. Carlton, 159-213. Springer Netherlands.

Cifuentes, L.A., J.H. Sharp, and M.L. Fogel. 1988. Stable carbon and nitrogen isotope biogeochemistry in the Delaware estuary. Limnology and Oceanography 33(5): 11021115. 
343 Cresson, P., S. Ruitton, and M. Harmelin-Vivien. 2016. Feeding strategies of co-occurring

$344 \quad$ suspension feeders in an oligotrophic environment. Food Webs 6: 19-28.

345 Crisp, D.J., and A.J. Southward. 1961. Different types of cirral activity of barnacles.

346 Philosophical Transactions of the Royal Society of London. Series B, Biological Sciences.

$347 \quad 243: 271-307$.

348 Decottignies, P., P.G. Beninger, Y. Rincé, and P. Riera. 2007. Trophic interactions between two introduced suspension-feeders, Crepidula fornicata and Crassostrea gigas, are influenced

350

351 by seasonal effects and qualitative selection capacity. Journal of Experimental Marine Biology and Ecology 342(2): 231-241.

352 Deegan, L.A., and R.H. Garritt. 1997. Evidence for spatial variability in estuarine food webs. Marine Ecology Progress Series 147: 31-47.

354 DeNiro, M.J., and S. Epstein. 1981. Influence of diet on the distribution of nitrogen isotopes in animals. Geochimica et Cosmochimica Acta 45: 341-351

Dix, N., and M.D. Hanisak. 2015. Microzooplankton grazing experiments in the subtropical Indian River Lagoon, Florida challenge assumptions of the dilution technique. Journal of Experimental Marine Biology and Ecology 465: 1-10.

Dolenec, T., S. Lojen, M. Dolenec, Ž. Lambaša, M. Dobnikar, and N. Rogan. 2006. ${ }^{15} \mathrm{~N}$ and ${ }^{13} \mathrm{C}$ Enrichment in Balanus perforatus: Tracers of Municipal Particulate Waste in the Murter Sea (Central Adriatic, Croatia). Acta Chimica Slovenica 53: 469-476. composition as a tracer of fish farming in invertebrates Aplysina aerophoba, Balanus perforatus, and Anemonia sulcata in central Adriatic. Aquaculture 262(2): 237-249. 
365 Dubois, S., F. Orvain, J.C. Marin-Léal, M. Ropert, and S. Lefebvre. 2007a. Small-scale spatial

366

367

368

369

370

371

372

373

374

375

376

377

378

379

380

381

382

383

384

385 variability of food partitioning between cultivated oysters and associated suspensionfeeding species, as revealed by stable isotopes. Marine Ecology Progress Series 336: 151160.

Dubois, S., B. Jean-Louis, B. Bertrand, and S. Lefebvre. 2007b. Isotope trophic-step fractionation of suspension-feeding species: implications for food partitioning in coastal ecosystems. Journal of Experimental Marine Biology and Ecology 351(1): 121-128.

Dubois, S.F., and F. Colombo. 2014. How picky can you be? Temporal variations in trophic niches of co-occurring suspension-feeding species. Food Webs 1: 1-9.

Freeman, C.J., and R.W. Thacker. 2011. Complex interactions between marine sponges and their symbiotic microbial communities. Limnology and Oceanography 56(5): 1577-1586.

Fukumori, K., M. Oi, H. Doi, D. Takahashi, N. Okuda, T.W. Miller, M. Kuwae, H. Miyasaka, M. Genkai-Kato, Y. Koizumi, and K. Omori. 2008. Bivalve tissue as a carbon and nitrogen isotope baseline indicator in coastal ecosystems. Estuarine, Coastal, and Shelf Science 79(1): 45-50.

Galimany, E., J. Lunt, C.J. Freeman, S. Reed, I. Segura-García, and V.J. Paul. 2017a. Feeding behavior of eastern oysters Crassostrea virginica and hard clams Mercenaria mercenaria in shallow estuaries. Marine Ecology Progress Series 567: 125-137.

Galimany, E., C.J. Freeman, J. Lunt, A. Domingos, P. Sacks, and L. Walters. 2017b. Feeding competition between the native oyster Crassostrea virginica and the invasive mussel Mytella charruana. Marine Ecology Progress Series 564: 57-66.

Peer) reviewing PDF | (2018:05:28109:1:1:NEW 23 Jul 2018) 
386 Garvis, S.K., P.E. Sacks, and L.J. Walters. 2015. Formation, movement, and restoration of dead

387 intertidal oyster reefs in Canaveral National Seashore and Mosquito Lagoon, Florida. Journal of Shellfish Research 34(2): 251-258.

389

390

391

393

394

395

396

397

398

399

400

401

402

403

404

405

406

407

408

Gili, J.M., and R. Coma. 1998. Benthic suspension feeders: their paramount role in littoral marine food webs. Trends in Ecology and Evolution 13(8): 316-321.

Gilmore, G.R., 1995. Environmental and biogeographic factors influencing ichthyofaunal diversity: Indian River Lagoon. Bulletin of Marine Science 57(1): 153-170.

Hsieh, H.L., W.Y. Kao, C.P. Chen, and P.J. Liu. 2000. Detrital flows through the feeding pathway of the oyster (Crassostrea gigas) in a tropical shallow lagoon: $\delta^{13} \mathrm{C}$ signals. Marine Biology 136(4): 677-684.

Jørgensen, C.B. 1974. On gill function in the mussel Mytilus edulis L. Ophelia 13: 187-232.

Kach, D.J., and J.E. Ward. 2008. The role of marine aggregates in the ingestion of picoplankton-size particles by suspension feeding molluscs. Marine Biology 153: 797-805.

Kamerosky, A., H.J. Cho, and L. Morris. 2015. Monitoring of the 2011 super algal bloom in Indian River Lagoon, FL, USA, using MERIS. Remote Sensing 7(2): 1441-1460.

Kang, Y., F. Koch, and C.J. Gobler. 2015. The interactive roles of nutrient loading and zooplankton grazing in facilitating the expansion of harmful algal blooms caused by the pelagophyte, Aureoumbra lagunensis, to the Indian River Lagoon, FL, USA. Harmful Algae 49: 162-173.

Karlson, A.M., E. Gorokhova, and R. Elmgren. 2015. Do deposit-feeders compete? Isotopic niche analysis of an invasion in a species-poor system. Scientific Reports 5: doi:10.1038/srep09715

Karlson, R.H., and R.W. Osman. 2012. Species composition and geographic distribution of 
invertebrates in fouling communities along the east coast of the USA: a regional perspective. Marine Ecology Progress Series 458: 255-268.

411

412

413

414

415

416

417

418

419

420

421

422

423

424

425

426

427

428

429

430

431

Lapointe, B.E., L.W. Herren, D.D. Debortoli, and M.A. Vogel. 2015. Evidence of sewagedriven eutrophication and harmful algal blooms in Florida's Indian River Lagoon. Harmful Algae 43: 82-102.

Lesser, M.P., S.E. Shumway, T. Cucci, and J. Smith. 1992. Impact of fouling organisms on mussel rope culture: interspecific competition for food among suspension-feeding invertebrates. Journal of Experimental Marine Biology and Ecology 165(1): 91-102.

MacKenzie, C.L. Jr, D.L. Taylor, and W.S. Arnold. 2001. A history of hard clamming. In Biology of the hard clam, eds. J.N. Kraeurer, and M. Castagna, 651-671. Elsevier, Amsterdam

Marchais, V., G. Schaal, J. Grall, A. Lorrain, C. Nerot, P. Richard, and L. Chauvaud. 2013. Spatial variability of stable isotope ratios in oysters (Crassostrea gigas) and primary producers along an estuarine gradient (Bay of Brest, France). Estuaries and Coasts 36(4): 808-819.

McCutchan, J.H., W.M. Lewis, C. Kendall, and C.C. McGrath. 2003. Variation in trophic shift for stable isotope ratios of carbon, nitrogen, and sulfur. Oikos 102: 378-390.

Michener, R.H., and L. Kaufman. 2007. Stable isotope ratios as tracers in marine aquatic food webs: An update. In Stable isotopes in ecology and environmental science, eds. R.H. Michener and K. Lajtha, 238-282. $2^{\text {nd }}$ edition. Oxford, UK: Blackwell Publishing Ltd. Møhlenberg, F., and H.U. Riisgård. 1978. Efficiency of particle retention in 13 species of suspension feeding bivalves. Ophelia 17(2): 239-246.

Petersen, J.K. 2007. Ascidian suspension feeding. Journal of Experimental Marine Biology and 
432

433

434

435

436

437

438

439

440

441

442

443

444

445

446

447

448

449

450

451

452

453

454

Ecology 342(1): 127-137.

Phlips, E.J., S. Badylak, M.A. Lasi, R. Chamberlain, W.C. Green, L.M. Hall, J.A. Hart, J.C. Lockwood, J.D. Miller, L.J Morris, and J.S. Steward. 2014. From red tides to green and brown tides: Bloom dynamics in a restricted subtropical lagoon under shifting climactic conditions. Estuaries and Coasts 38(3): 886-904.

Post, D.M. 2002. Using stable isotopes to estimate trophic position: Models, methods, and assumptions. Ecology 83(3): 703-718.

Ricciardi, A., and E. Bourget. 1999. Global patterns of macroinvertebrate biomass in marine intertidal communities. Marine Ecology Progress Series 185: 21-35.

Richoux, N.B., I. Vermeulen, and P.W. Froneman. 2014. Stable isotope ratios indicate differential omnivory among syntopic rocky shore suspension-feeders. Marine Biology 161(5): 971-984.

Riisgård, H.U. 1988. Efficiency of particle retention and filtration rate in 6 species of Northeast American bivalves. Marine Ecology Progress Series 45(3): 217-223.

Riisgård, H.U., and P. Manríquez. 1997. Filter-feeding in fifteen marine ectoprocts (Bryozoa): Particle capture and water pumping. Marine Ecology Progress Series 154: 223-239.

Riisgård, H.U., and P.S. Larsen. 2010. Particle capture mechanisms in suspension-feeding invertebrates. Marine Ecology Progress Series 418: 255-293.

SJRWMD (St. Johns River Water Management District). 2013. The Indian River Lagoon: An estuary of national significance Floridaswater.com, http:// floridaswater.com/itsyourlagoon/.

Smith, N.P. 1993. Tidal and nontidal flushing of Florida’s Indian River Lagoon. Estuaries and Coasts 16(4): 739-746. 
455 Stuart, V., and D.W. Klumpp. 1984. Evidence for food-resource partitioning by kelp-bed filter 456 feeders. Marine Ecology Progress Series 16: 27-37.

457 Swain, H.M., D.R. Breininger, D.S. Busby, K.B. Clark, S.B. Cook, R.A. Day, D.E. De Freese, 458 R.G. Gilmore, A.W. Hart, C.R. Hinkle, D.A. McArdle, P.M. Mikkelsen, W.G. Nelson, 459 and A.J. Zahorcak. 1995. Indian River Lagoon conference - introduction. Bulletin of $460 \quad$ Marine Science 57(1): 1-7.

461 Whalen, M.A., and J.J. Stachowicz. 2017. Suspension feeder diversity enhances community 462 filtration rates in different flow environments. Marine Ecology Progress Series 570: 1-13.

463 Wilson, C., L. Scotto, J. Scarpa, A. Volety, S. Laramore, and D. Haunert. 2005. Survey of water 464 quality, oyster reproduction and oyster health status in the St. Lucie Estuary. Journal of $465 \quad$ Shellfish Research 24(1): 157-165.

466 Zanden, M.J.V., and J.B. Rasmussen. 2001. Variation in $\delta^{15} \mathrm{~N}$ and $\delta^{13} \mathrm{C}$ trophic fractionation: 467 Implications for aquatic food web studies. Limnology and Oceanography 46: 2061-2066. 468 469 470 471 472 


\section{Figure 1}

Map of 29 permanent monitoring sites established in the three sublagoons (Banana River [B], Indian River Lagoon [I], and Mosquito Lagoon [M]) of the Northern IRL of central Florida (inset map).

Map data: Google, SIO, NOAA, U.S. Navy, NGA, GEBCO and Landsat/ Copernicus

*Note: Auto Gamma Correction was used for the image. This only affects the reviewing manuscript. See original source image if needed for review. 


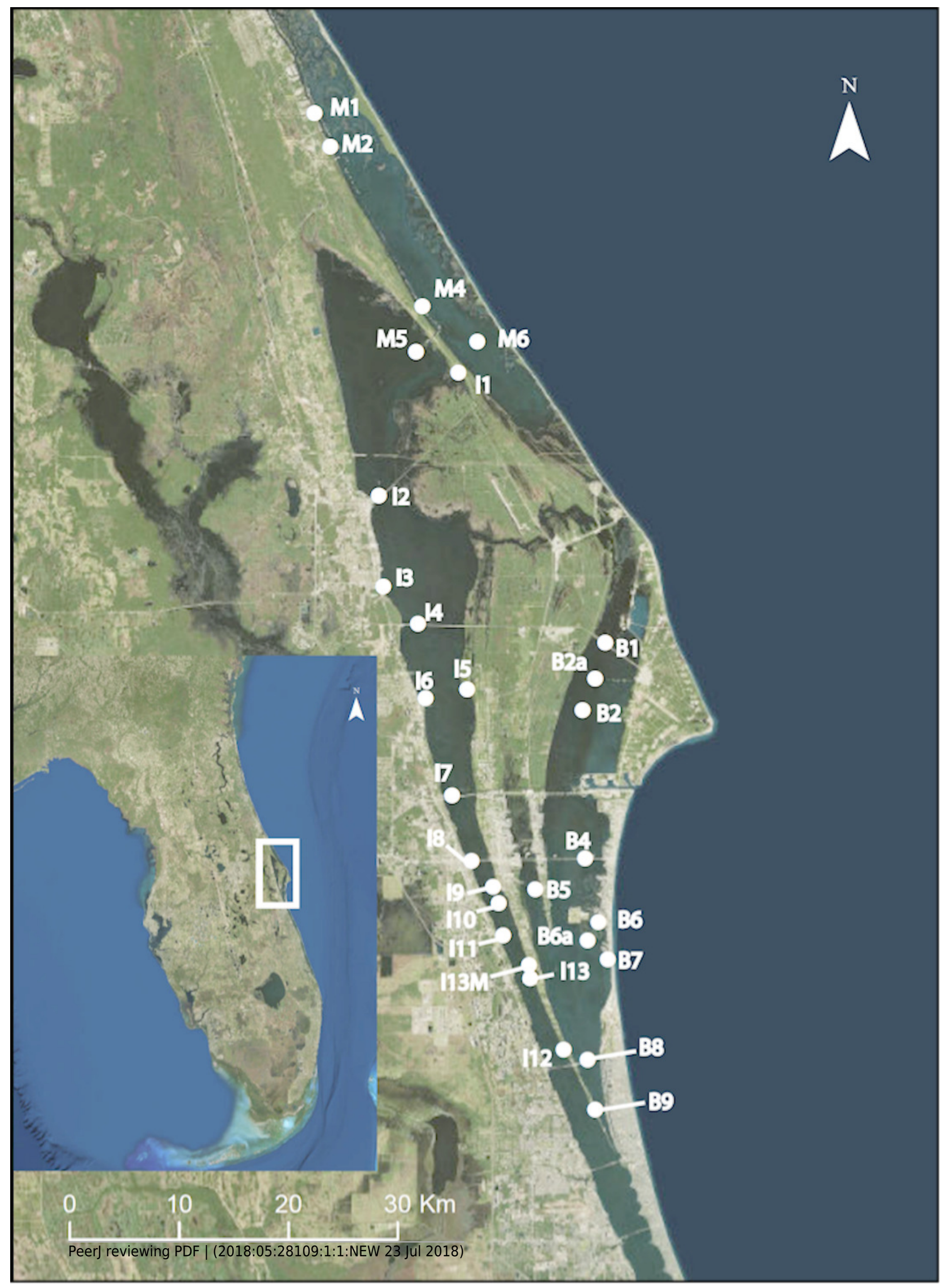


Figure 2

Mean (+/-SE) $\delta^{15} \mathrm{~N}$ values of Amphibalanus eburneus tissue (a) and particulate organic matter (POM; b) at individual sites within the three sublagoons of the northern Indian River Lagoon.

Sublagoons include the Banana River [B], Indian River Lagoon [I], and Mosquito Lagoon [M]. Data are shown as annual means (from each season from January to October of 2015) and mean ( $A$. eburneus tissue) and single POM values from an Aureoumbra lagunensis bloom in January 2016
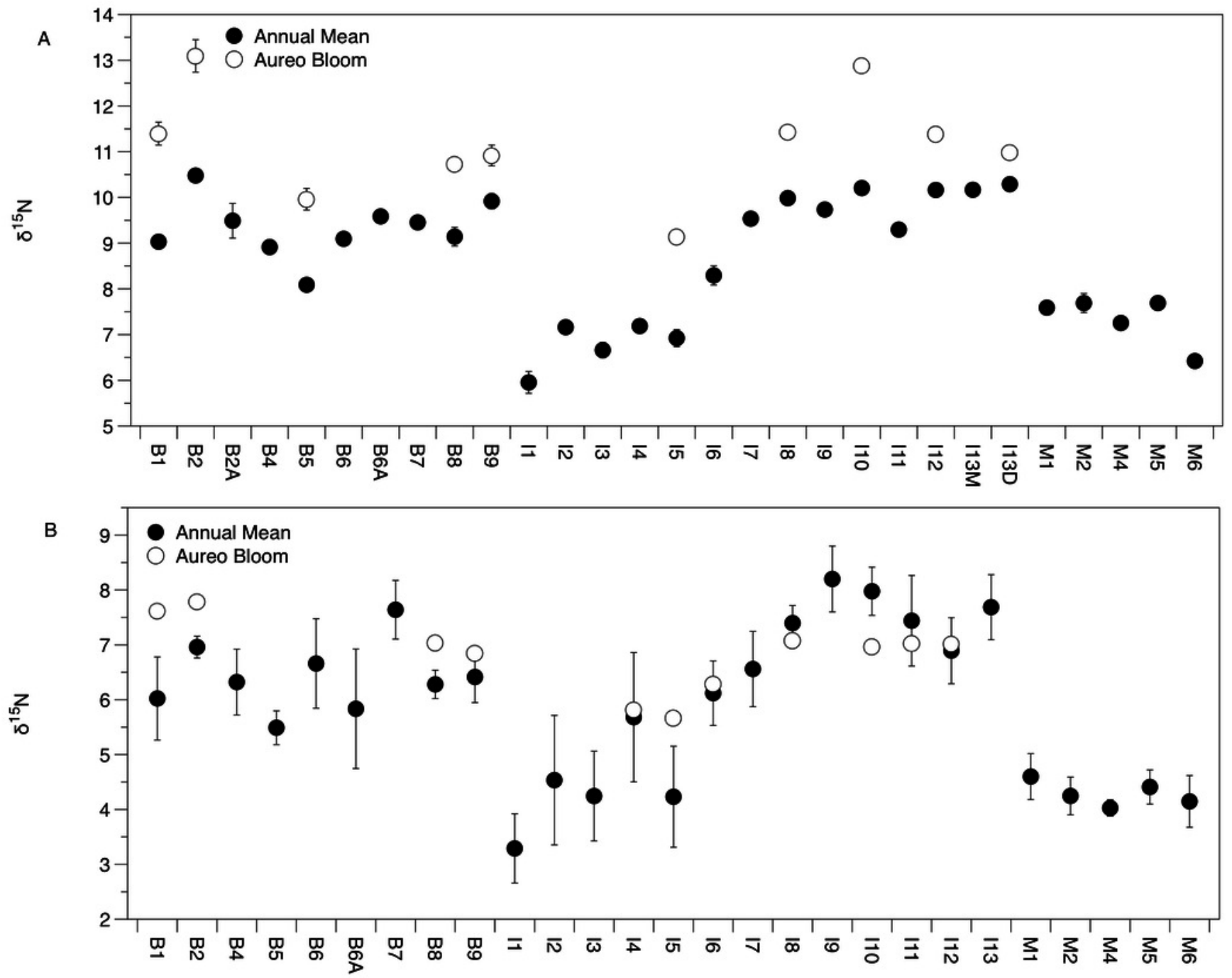
Figure 3

Mean (+/-SE) $\delta^{13} \mathrm{C}$ values of Amphibalanus eburneus tissue (a) and particulate organic matter (POM; b) at sites within the sublagoons of the northern Indian River Lagoon.

Sublagoons include the Banana River [B], Indian River Lagoon [I], and Mosquito Lagoon [M]. Data are shown as annual mean (from each season from January to October of 2015) and mean (A. eburneus tissue) and single POM values from an Aureoumbra lagunensis bloom in January 2016.
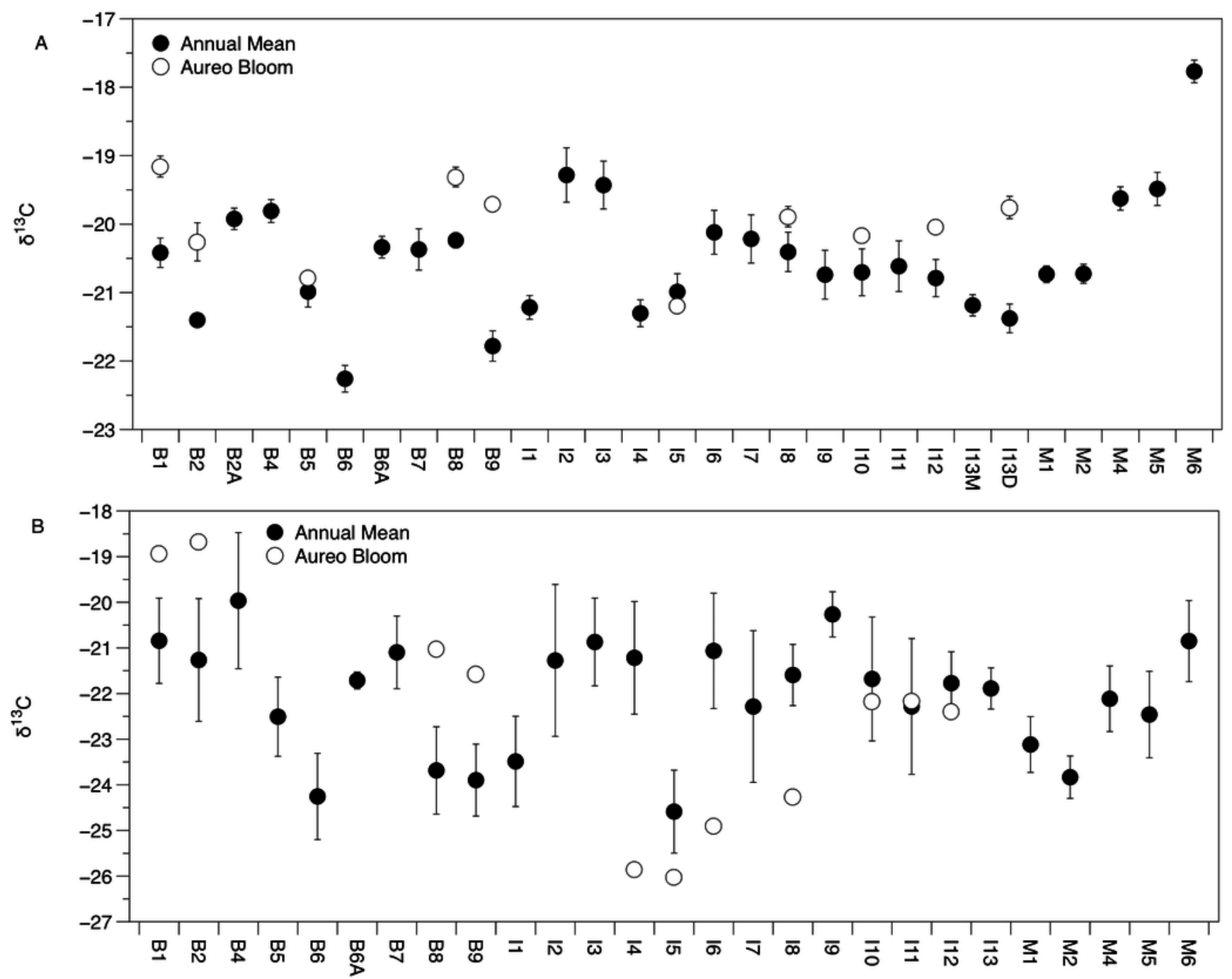


\section{Figure 4}

Mean (+/- SE) $\delta^{15} \mathrm{~N}(\mathrm{a})$ and $\delta^{13} \mathrm{C}$ (b) values of Amphibalanus eburneus tissue at a site as a function of mean (+/-SE) $\delta^{15} \mathrm{~N}$ and $\delta^{13} \mathrm{C}$ value of particulate organic matter (POM) at the same site.

Data include 29 sites within the sublagoons of the northern Indian River Lagoon. Tissue and POM samples were taken each season from January to October of 2015 (shaded circles) and also during an Aureoumbra lagunensis bloom in January of 2016 (open circles) 

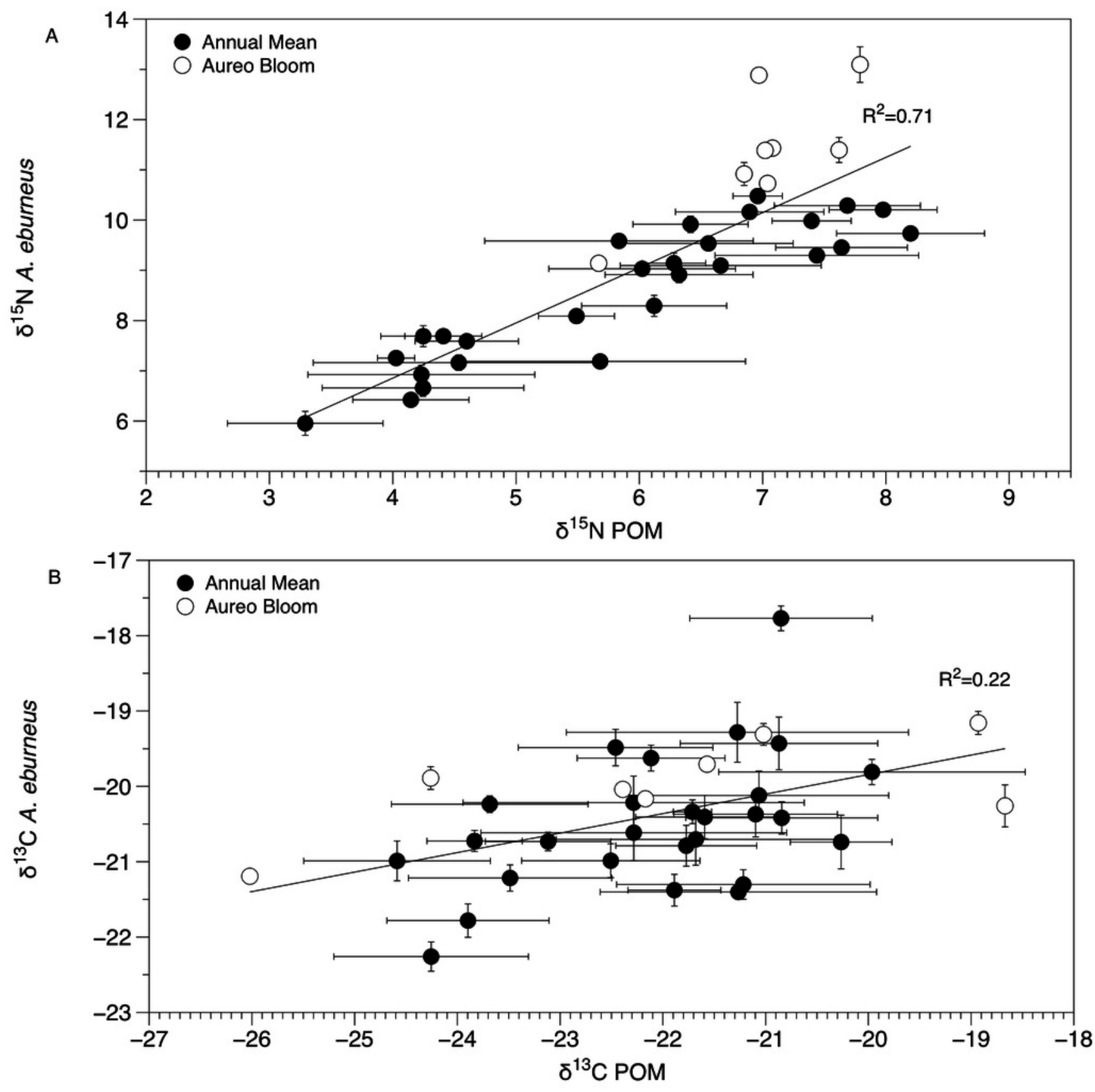
Figure 5

Mean (+/- SE) $\delta^{15} \mathrm{~N}$ and $\delta^{13} \mathrm{C}$ values of Amphibalanus eburneus for each season from January to October of 2015 and during an Aureoumbra lagunensis bloom in January 2016.

Values were calculated from $\delta^{15} \mathrm{~N}$ and $\delta^{13} \mathrm{C}$ values of $A$. eburneus from all sites within the three sublagoons of the Northern Indian River Lagoon.

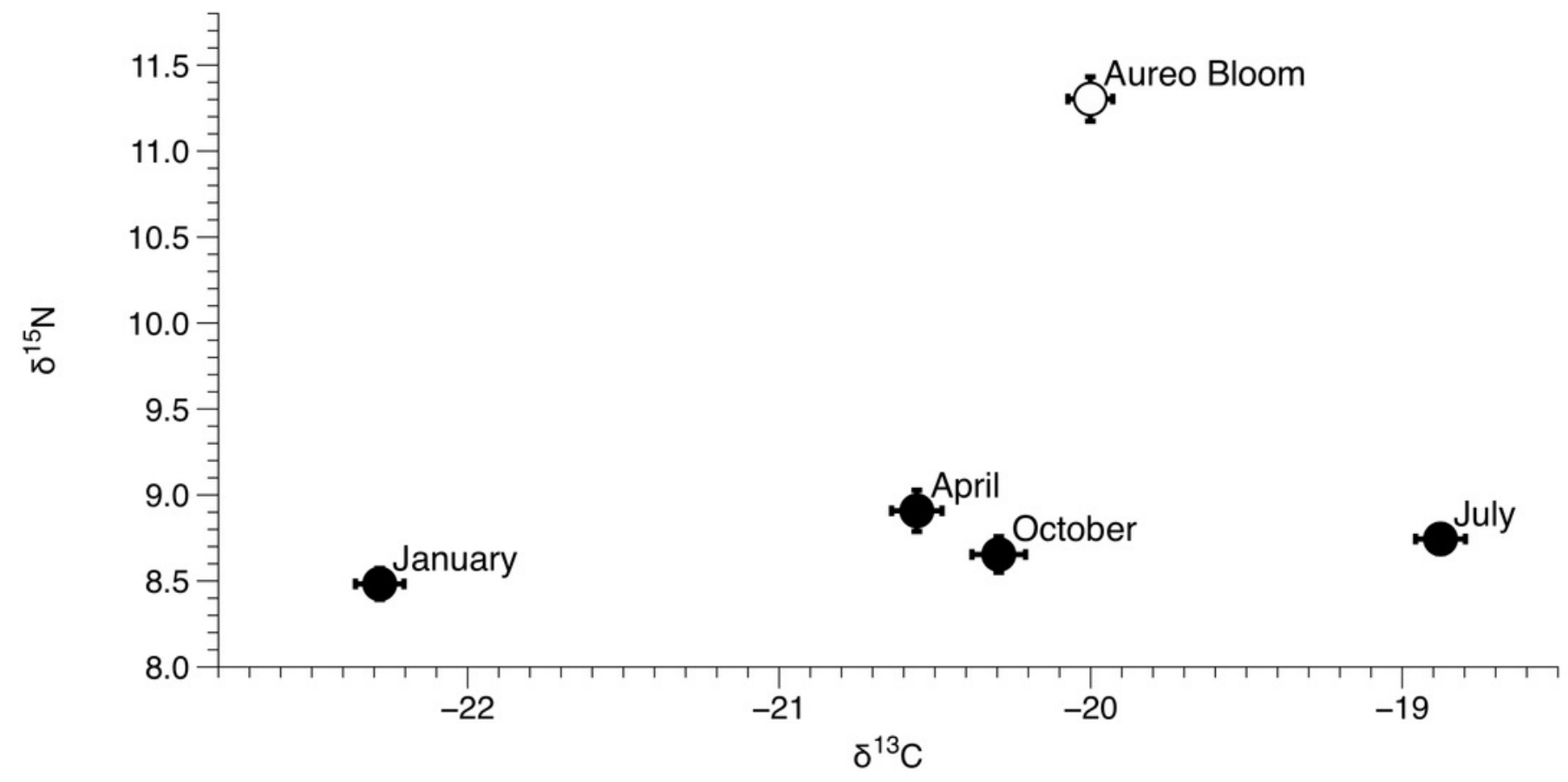

